\title{
Múszaki szabályozási érdekességek az Európai Unió és az Egyesült Királyság megállapodásából
}

\section{Technical Regulatory Issues from the Agreement between the European Union and the United Kingdom}

A Brexit-folyamat legvégső pillanatában, egy az EU-Kanada szabadkereskedelmi egyezmény (CETA) mintájára létrehozott és 2020. december 30-án aláirt kereskedelmi és együttmüködési megállapodással sikerült a liberalizált árumozgás megtartása az aláíró felek között. Az európai belső piacon szabadon forgalmazható, összes árura vonatkozó EU-s müszaki jogszabályok továbbra is kötelezők az EK exporttermékeire az Európai Gazdasági Térség (EGT) 31 országában, de most már nem feltételek nélkül érvényesek az EK-ban, mint arra az átmeneti idöszakra vonatkozóan kötelezettséget vállaltak, hanem csak a megállapodásban rögzített módon, amire érdemes felhívni mind a jogalkotók, mind a bilaterális kereskedelemben részt vevö felek szíves figyelmét, és megemlíteni egy ezzel összefüggő gazdaságpolitikai kérdést.

Kulcsszavak: Kereskedelmi és Együttműködési Megállapodás, Kereskedelmi Világszervezet, kereskedelem technikai akadályai, műszaki (tartalmú) előírás/ jogszabály, szabvány, megfelelőségértékelés, régi/új/általános megközelítés, ENSZ EGB - Egyesült Nemzetek Szervezete Európai Gazdasági Bizottsága

At the very last moment of the Brexit process, a trade and cooperation agreement modeled on the EU-Canada Free Trade Agreement (CETA) and signed on 30 December 2020 succeeded in maintaining the liberalised movement of goods between the signatories. The EU technical regulation for all goods that can be freely traded on the European internal market remains binding on U.K. exports to the EEA-31, but is no longer unconditionally in force in the U.K. as was commited for a transitional period; but only in the way set out in the Agreement, to which it is worth drawing

Okleveles mérnök, a műszaki tudományok kandidátusa, a Magyar Tudományos Akadémia köztestületi és az MMA - mérnökakadémia tagja. 
the kind attention of both legislators and parties involved in bilateral trade while mentioning a related economic policy issue.

Keywords: Trade and Cooperation Agreement, WTO - World Trade Organization, TBT - Technical Barriers to Trade, Technical Regulation, Standard, Conformity Assessment, old/new/global approach, UNECE - United Nations Economic Commission for Europe

\section{Az Európai Unió - Egyesült Királyság megállapodásának rövid jellemzése}

A hároméves tárgyalás után, de a véghatáridő előtt egy nappal „sebtében” aláírt 1300 oldalas kereskedelmi megállapodásra² ${ }^{2}$ négy hónapos intenzív szövegpontosító munka várt a folyó év április 29-én megtörtént határozathozatalig. Ennek ellenére még jelenleg is értelmezési vita dúl a felek között számos kérdésben, de ezek lezárásának megvárását nem tartom szükségesnek, mert a Megállapodás egyes áruféleségekre vonatkozó müszaki szabályozásának példaszerű elemzése a hatályos jogszabály alapján megtehető, és így megérthető a Határozat 5. cikke szerinti 2023. december 31-ig elvégzendő újraértékelés szükségessége is, amellyel lényegében az Egyesült Királyságban (EK) kibocsátott termékek egyenértékűségét vizsgálnák és értékelnék, az Európai Unió (EU) műszaki jogszabályi környezetében gyártottakhoz képest.

A Megállapodás, bár az EU legfejlettebb ilyen egyezményét, a CETA-t veszi alapul, ${ }^{3}$ mégis „visszalépés” az európai belső piac szabadkereskedelmi övezet létrehozási folyamatának korai állapotába, amikor a vámok és mennyiségi korlátozások felszámolásával és a vámunió kialakításával, illetve közös külső vámtarifa alkalmazásával tervezték az áruk szabad mozgását megteremteni. A Megállapodás árukra vonatkozó része a Kereskedelmi Világszervezet egyezményén (angol rövidítéssel: WTO, korábban GATT) alapul és liberalizált kereskedelem folytatását célozza. Részletesen tárgyalja a WTO-alapelveket a műszaki szabályozást illetően; nevezetesen a mintául szolgáló CETA-hoz hasonlóan. A 90-93. cikkekbe emeli át az úgynevezett „TBT- kereskedelem technikai akadályai” kérdéseket, így a műszaki előírásokat/jogszabályokat (91. cikk), a szabványokat (92. cikk) és a termékek megfelelőségének értékelését (93.cikk). Ezek Megállapodásban történő szerepeltetését indokolják az EU egységes belső piac kialakulásának időszakában az árumozgást korlátozó intézkedésekkel kapcsolatos tapasztalatok, amelyek például a tagországok eltérő műszaki szabályozásából adódtak, és amelyek

A Tanács (EU) 2021/689 határozata (2021. április 29.) egyrészről az Európai Unió és az Európai Atomenergia-közösség, másrészről Nagy-Britannia és Észak Írország Egyesült Királysága közötti kereskedelmi és együttműködési megállapodásnak, valamint az Európai Unió és Nagy-Britannia és Észak-Írország Egyesült Királysága közötti, a minősített adatok cseréjére és védelmére vonatkozó biztonsági eljárásokról szóló megállapodásnak az Unió nevében történő megkötéséről. (A továbbiakban Megállapodás.)

Az EU és Kanada között létrejött szabadkereskedelmi egyezmény (CETA): https://ec.europa.eu/trade/ policy/in-focus/ceta 
a kötelező tanúsításokkal, az országhatár átlépésekor megismételt (laboratóriumi) vizsgálatokkal lassították az áruk áramlását, de szélsőséges esetben meg is bénították a szabad mozgást.

A Megállapodás e szakcikk célkitűzésétől eltérő, tarifális részével csak ebben a bekezdésben foglalkoznék, példaszerűen egy termékre vonatkozóan, ahol az előírás időbeli változása mintha a fejlesztési elvvel ellentétesen módosulna. Itt a Harmonizált Áruleíró és Kódrendszer XV. áruosztályába tartozó Alumínium és ezekből készített áruk (76.03-76.07 nómenklatúra) kereskedelmi kontingensét mindkét irányban 95000 tonnában maximalizálja 2021. január 1-je és 2023. december 31-e között. E termék preferált mennyisége a periódus utáni két évben csökken 72000 tonnára, majd 57500 tonna értékben maximalizálódik, azaz idővel, ha nem is épül le a liberalizált kereskedelem, de a kivezetés irányába tart.

\section{A Megállapodásban említett múszaki tartalmú jogalkotás jellemzése}

A műszaki szabályozás egy fejlett ipari demokráciában jogszabályokkal történik, amelyekkel az állam a termékekre kötelezően betartandó technikai követelményeket és ezek betartását biztosító magatartási formát ír elő. Az állam a múszaki tartalmú jogszabályaival a termékeket használó vagy szolgáltatásokat igénybe vevő fogyasztók biztonságát kívánja szavatolni, kielégítve azt az alapvető állampolgári jogot, amely a biztonságos termékhez, szolgáltatáshoz kapcsolódik. A biztonság fogalma sok tényezőtől függ, az adott kor természettudományos ismereteinek, a felhasználói kör képzettségének függvényében, és belátható, hogy a veszélyek teljes és minden formájának kizárása az ipari termékek esetében csak aránytalanul nagy költséggel közelíthető a 100\%-hoz, de az soha nem érhető el.

Ugyanakkor az eltérő múszaki szabályozás akadálya is lehet az országok közötti árumozgásnak, mint azt előbb említettük az egységes európai belső piac megteremtésének tapasztalatai között, és ennek feloldására nemzetközi munka indult az ENSZ szakosított szervezeteinek keretében. A Kereskedelmi Világszervezet az 1979. évi Tokiói Forduló nyomán szólította fel tagállamait a kereskedelem technikai akadályát jelentő műszaki jogszabályok és a hasonló módon funkcionáló szabványok egymás számára történő rendelkezésre bocsátására, az ilyenek megalkotásának elkerülésére, illetve lebontására, a nemzeti műszaki szabályozás szerinti megfelelőségértékelési eljárásokhoz történő nemzetközi hozzáférésre és az értékelési tevékenység kölcsönös elismerésére. Ez a politika tovább erősödött az Uruguay-i Forduló lezárását követően, és mára például az EU új szabadkereskedelmi megállapodásainak ${ }^{4}$ részévé vált.

Az EU-EK Megállapodás 94-100. cikkeiben találjuk a Kereskedelmi Világszervezet ajánlásának megfelelő, átláthatóságra, helyes szabályozásra és együttműködésre

A Kereskedelmi Világszervezet ajánlásán alapuló úgynevezett Helyes Szabályozási Gyakorlat. European Commission: Good Regulatory Practices (GRPS) in TTIP - An introduction to the EU's revised proposal (2016. március 21.).

Európai Tükör 2021/2. 
vonatkozó rendelkezéseket. Ezek betartása egyik fél számára sem lehet nagy probléma, mert például az EU valójában nem volt képes mindent, így a teljes belső piaci termékkört 100\%-ban lefedő technikai szabályozás megalkotására, hanem csak ott alkotott, illetve alkot jogszabályt, ahol a hibás termék nagy kockázatot jelent az élet- és a vagyonbiztonság szempontjából. Az EU jogalkotása talán csak az egészség- és napjainkban leginkább a környezetvédelem területén lehet ezen ajánlás szempontjából aggályos, ahol az elővigyázatossági megközelítés ${ }^{5}$ alapján alkotott jogszabályokban olyan kockázatokat is kezelnek, amelyek tudományos megítélése még bizonytalan. A Megállapodás keretében a felek műszaki előírásnak/jogszabálynak tartják az EU-ban az Európai Unió múködéséről szóló szerződés 288. cikke szerinti rendeleteket és irányelveket, továbbá a 290. és 291. cikkek szerinti bizottsági és tagországi jogalkotási aktusokat, illetve az EK-ban az elsődleges és másodlagos jogalkotást (amelyek magyar megfelelői a műszaki szabályozás megvalósításában: az Országgyúlés által elfogadott törvény, a Kormány által kiadott kormányrendelet és a miniszter vagy miniszterek által jóváhagyott miniszteri rendelet).

A WTO ajánlásának megfelelően tartalmazzák a felek közötti együttmúködés szabályozását a Megállapodás 94-97. cikkei az információszolgáltatásra, a megfelelőségértékelésre stb. vonatkozóan. A 98. és 100. cikk szabályozza a kereskedelem technikai akadályaival foglalkozó kereskedelmi szakbizottság munkáját, míg a 99. cikk egy Információs Pont létesítését írja elő a felek közötti információáramlás megkönnyítésére.

\section{A Megállapodásban nem említett, de az EK-ban jelenleg még hatályos múszaki jogszabályok}

Az EK mint 1973-tól EU-tagország, részese volt olyan ágazati vagy régi típusú irányelvi jogalkotásnak, amelyet az európai műszaki szabályozás az egységes belső piac kialakításának kezdeti szakaszában (1968-1985) használt az áruk területén. Ilyen típusú jogszabályok jellemzik ma is a közösségi műszaki tartalmú jogi szabályozást - és ezek harmonizációja révén a britet is - az élelmiszerek, a gyógyszerek, a gépjármúvek, a traktorok és más mezőgazdasági gépek, valamint a kozmetikumok, illetve egyes vegyi anyagok esetében. Ezt követően az EU-s (és így a brit) jogalkotásban teret nyert az új megközelítés elve, amely egy nagy termékkör használatával kapcsolatos általános kockázatok elemzésén és a veszély megelőzésén alapul. Az új megközelítésű direktívákban olyan általános, alapvető követelményeket fogalmaznak meg forgalmazási feltételként a termékek szélesebb körére, mint az egészségvédelem, a higiénia, az üzembiztonság, a tűzvédelem és a környezetvédelem. Egy termékkörre több irányelv is vonatkozhat, ilyenkor a mindegyikben megfogalmazott követelmény teljesítése szükséges a közösségi piacon történő forgalmazáshoz. Ebben segíthet a jogforrásnak nem minősülő, de az európai szabványosító szervezetek által kiadott úgynevezett harmonizált műszaki szabványok szerinti megfeleltetés, amely a tagállami szabványosítás révén épül a nemzeti rendszerbe.

Az EU Bizottság /2000/0001 sz. közleménye ismerteti az elővigyázatosság elvének jogszabályi alkalmazásának feltételeit olyan kockázatok kezelésénél, ahol a tudományos ismeretek még nem teljesek. 
Az EU-beli műszaki szabályozás azonos tagországi érvényesüléséhez még szükség volt az alkalmazás egységesítésére, amelyet nem irányelvvel, hanem a Közösségben közvetlenül és kötelezően megvalósuló jogszabállyal vezettek be. Ilyen például a 768/2008/EK határozat, amely EU-méretú megközelítést alkalmaz a vizsgálat és a tanúsítás területén. E globális megközelítés elve szerint az irányelvekben megadják azokat a megfelelőségértékelési eljárásokat, amelyeken egy-egy adott terméknek át kell esnie ahhoz, hogy az EU belső piacán szabadon kereskedelmi forgalomba kerülhessen. Ezek az eljárások áru- és irányelvfüggők, és ennek megfelelően jelentősen eltérhetnek egymástól. Sokszor elegendő a forgalmazáshoz a gyártó (szállító, importőr) megfelelőségi nyilatkozata az alapvető követelmények kielégítéséről, míg a hibás működéssel nagyfokú veszélyt jelenthető termékek esetében független, harmadik fél általi típus, illetve gyártási eljárás, teljes minőségügyi rendszer tanúsítása stb. szükséges.

Az EU múszaki szabályozásának teljessé tételét szolgálta az a rendelet, amely nemzeti akkreditálás és piacfelügyelet vonatkozásában állapít meg egységes uniós szabályokat. Megemlítendő, hogy néhány szakterületen tagországi átültetést szintén nem igénylő rendelettel oldják meg a szabályozást, ilyen például a REACH, illetve a GHS jogszabály (bemutatásuk a továbbiakban), amelyek a vegyi anyagok területének alapjogszabályai.

Joggal vethető fel a kérdés, hogy miért választotta az EK a CETA-típusú megállapodást, amellyel elvész a teljes múszaki szabályrendszere, illetve olyan hézagok keletkeznek benne, mint az utóbbi szakaszban feltüntetett EU-s rendeletekkel megvalósított horizontális szabályozás, azaz érdemes-e elhagyni az EU-rendszert és szuverén múszaki szabályozást létrehozni?

E kérdésre is sokan kíséreltek meg választ adni, hiszen tanulmánykötetek születtek a Brexit különböző szempontú vizsgálatáról. Megállapították, ${ }^{6}$ hogy az európai belső piacnak/gazdasági térnek (EGT) használói csak azok lehetnek, akiknek országa a szabadságjogokhoz tartozó teljes jogszabályrendszert átveszi. Így értelemszerűen a tagországok vagy az az állam, amely erre kötelezettséget vállalt az EGT-szerződés aláírásával (például Norvégia) vagy külön megállapodásokkal (Svájc).

Negatívumot nem ismertettek az EU műszaki jogszabályrendszerének működésével, biztonságosságával összefüggésben, viszont egy hivatkozott tanulmányban ${ }^{7}$ szerepel, hogy 56 vizsgált jogszabály alkalmazásából adódó veszteség a brit GDP 0,9\%-át tette ki 2015-ben. Tekintettel e jogszabályok felsorolásának hiányára, nem azonosítható, hogy ezekből mennyi az áruk szabad mozgását a belső piacon biztosító jogszabály, de e nélkül is - a Megállapodás egy-egy mellékletének példaszerű elemzésével - megválaszolható a fenti kérdés.

A gépjárművek vagy a gyógyszerek területén az előző fejezetben említett ágazati, avagy „old approach” jogalkotás jellemzi az EU múszaki szabályozását, amely nagy összhangban fejlődött a nemzetközi és az ENSZ szakosított szervezeteiben végzett egységesítő tevékenységgel. Erre az alapra helyezi vissza a terület jogi szabályozását a Megállapodás e fejezethez tartozó első és második melléklete (gépjármúvek, illetve

Swati Dhingra and Thomas Sampson: Life after Brexit. London, Centre for Economic Performance, (é. n.). 4-9.

Swati Dhingra et al.: The consequences of Brexit for UK trade and living standards. London, Centre for Economic Performance, (é. n.). 9. 
gyógyszerek). Tekintettel arra, hogy itt az EU-jogi szabályozás összhangban van a nemzetközi műszaki szabályozással, ${ }^{8}$ és a megfelelő EK-beli jogszabályi háttér (változtatás nélkül) szintén rendelkezésre áll, a jövőben is adott lesz a technikailag akadálymentes árucsere a Megállapodás értelmében.

A gépjárművekre és alkatrészeikre vonatkozóan a Megállapodással a felek elismerik az ENSZ EGB „WP-29” szabályozások egységesítését végző Fóruma által kibocsátott szabványokat. Minden idetartozó terméket típusvizsgálatnak kell alávetni, hogy megfelel-e a vonatkozó biztonsági követelményeknek. Egyes termékek típustanúsítvány szerinti megfelelősége a feltétele a piacra helyezésnek, a másik félnél történő forgalomba állításnak.

A humán és állatgyógyászati termékekre vonatkozóan a Megállapodással a felek kijelölik a Jó Gyártási Gyakorlat végrehajtásáért felelős hatóságokat (az összes tagország hatósága, benne a magyar Országos Gyógyszerészeti és Élelmezés-egészségügyi Intézet, Nemzeti Élelmiszerlánc-biztonsági Hivatal, illetve a brit illetékes hatóságok), amelyek jogosultak ellenőrzésre a gyógyszergyártóknál, illetve a másik fél által kiállított, egyegy termék piaci forgalomba bocsátását engedélyező dokumentum megismerésére, azaz a hatósági jogköröket a felek fenntartják maguknak.

Nem kerül bajba a Megállapodással az EK olyan területen sem, ahol az új megközelítés irányelveinek átültetett jogszabályai szabályozzák a piacra jutást. A korszerü ipari termékek nagy volumenét szabályozzák egységesen az EU-ban a kisfeszültségú vagy a nyomástartó berendezésekre, illetve a gépekre stb. vonatkozó jogszabályok. ${ }^{9}$ E műszaki jogszabályok hatálya alá tartozó termékek megfelelőségét általában a gyártó tanúsítja (összhangban a TBT 6. cikke ajánlásával), így szinte észrevehetetlen, hogy például egy brit gyártó háztartási gépe már nem az EU28, hanem az UK-EU27 között kötött megállapodással kerül forgalomba a belső piacon.

Más viszont a helyzet a vegyi anyagok területén, amelyet a Megállapodás 3. melléklete szabályoz, és ahol egy újabb EU-jogalkotási módszer szerint irányelv helyett rendeletet alkottak, amely nem igényelt tagállami jogi aktust. A területet nagymértékben lefedő két jogszabály, ${ }^{10}$ a REACH és a GHS közül csak az utóbbit, az anyagok és keverékek

Az ENSZ EGB keretében folyik a gépjárművekre, illetve az ENSZ szakosított szervezeteiben a gyógyszerekre vonatkozó műszaki jogszabályfejlesztés. Bővebben lásd: www.kti.hu/kutatas/eu-es-ensz-egb-kozuti-jarmu-muszaki-koordinacio-ekk/ensz-gepjarmu-eloirasok/

Schuchtár Endre és szerzőtársai: Gyakorlati Tudnivalók az EU-ról GKM Bp. 2004. 32-33.

10 Az Európai Parlament és a Tanács 1907/2006/EK rendelete (2006. december 18.) a vegyi anyagok regisztrálásáról, értékeléséről, engedélyezéséről és korlátozásáról (REACH), az Európai Vegyianyag-ügynökség létrehozásáról, az 1999/45/EK irányelv módosításáról, valamint a 793/93/EGK tanácsi rendelet, az 1488/94/EK bizottsági rendelet, a 76/769/EGK tanácsi irányelv, a 91/155/EGK, a 93/67/ EGK, a 93/105/EK és a 2000/21/EK bizottsági irányelv hatályon kívül helyezéséről illetve, Az Európai Parlament és a Tanács 1907/2006/EK rendelete (2006. december 18.) a vegyi anyagok regisztrálásáról, értékeléséről, engedélyezéséről és korlátozásáról (REACH), az Európai Vegyianyag-ügynökség létrehozásáról, az 1999/45/EK irányelv módosításáról, valamint a 793/93/EGK tanácsi rendelet, az 1488/94/ EK bizottsági rendelet, a 76/769/EGK tanácsi irányelv, a 91/155/EGK, a 93/67/EGK, a 93/105/EK és a 2000/21/EK bizottsági irányelv hatályon kívül helyezéséről (EGT vonatkozású szöveg); Az Európai Parlament és a Tanács 1272/2008/EK rendelete (2008. december 16.) az anyagok és keverékek osztályozásáról, címkézéséről és csomagolásáról, a 67/548/EGK és az 1999/45/EK irányelv módosításáról és hatályon kívül helyezéséről, valamint az 1907/2006/EK rendelet módosításáról (EGT-vonatkozású szöveg). 
osztályozásáról, címkézéséről és csomagolásáról szólót említjük mint a felek számára elfogadható ENSZ Harmonizált Rendszerdokumentumot (UN GHS). Itt az anyagok és keverékek kereskedelmének műszaki előfeltételét szabályozó, a regisztrációt, értékelést, korlátozást és az engedélyezést előíró jogszabálya (angol rövidítéssel: REACH) csak az EU-nak van, és az ide való belépésre csak az előírást teljesítő termék szerez jogosultságot.

Kézenfekvő lenne az EK számára a REACH-nek a GHS-hez hasonló brit rendeleti kiadása és így a műszaki szabályozási rendszerükben keletkezett rés betömése, és ennek a Megállapodásban történő szerepeltetése, de nem lépett erre az útra. Mielőtt ennek vizsgálatát megtennénk a következő szakaszban, megválaszolható az a kérdés, hogy a Megállapodással az EK bizonyítottan nem hagyja el az EU műszaki szabályozási rendszerét, de néhány eleménél/területen megfontolással él, ami hatással lehet a termékeinek egyenértékűségére.

\section{A REACH rövid jellemzése, kereskedelmi hatása}

A REACH az Európai Unió rendelete, amelynek célja, hogy az európai uniós vegyipar versenyképességének javítása mellett fokozza az emberi egészség és a környezet védelmét a vegyi anyagok által potenciálisan okozott kockázatokkal szemben. Az EU-ban 2007 óta hatályban lévő jogszabály első tíz éve alatt az uniós vegyipar árbevétele stagnált, 2017-ben 542 milliárd euró volt, amelyből 6,7\% a brit részesedés. ${ }^{11}$ Míg az EU világkereskedelemben képviselt aránya 2007-ben 27,5\% volt, addig ez az érték 2017-ben már csak 16\%, a Kína vezetésével feltörekvő országok termelésnövekedése miatt, és az EU27 világpiaci részesedése várhatóan már csak 10,5\% lesz 2030-ban.

A REACH-rendeletben foglalt kötelezettségek - például regisztrálás - teljesítése az Európai Unióban székhellyel rendelkező importőr, illetve az itt székhellyel rendelkező, nem uniós gyártó kizárólagos képviselőjének a feladata, így a Megállapodás mellékletében foglaltak már kedvezőtlenebb adminisztrációs helyzetbe hozzák a brit vegyipari vállalkozót, de ez feltehetően nem fogja a meglévő piaci helyzetüket rontani, legalábbis rövid távon.

A REACH-jogszabály az elővigyázatossági megközelítést alkalmazza, azaz olyan kockázatokat is kezel, amelyek tudományos megítélése még bizonytalan. Egy 2020-as javaslat ${ }^{12}$ szerint a közeljövőben megtiltják, hogy a termékbe kis méretű műanyagokat (microplastics) építsenek be, ha ezek lebomlása a környezetben nem lehetséges. A jogszabályi korlátozással csökkenthető lesz évente 13 200-95 000 tonnával a természetbe jutó mikroműanyag mennyisége, amely veszélyességének megítélése azonban tudományosan vitatott: például egészségkárosító-e vagy „csak” szemét, amely a gépjármű gumiabroncsok kopása következtében különben is megállíthatatlanul növekszik a környezetben. A korlátozás 2,1-20,6 milliárd eurós éves kiadást jelent az uniós

\footnotetext{
11 Az Európai Vegyipari Szövetség (CEFIC) éves jelentése alapján: CEFIC: 2021 Facts And Figures Of The European Chemical Industry (é. n.).

12 Az Európai Vegyi-anyag Ügynökség véleménye: European Chemicals Agency: Scientific committees: EU-wide restriction best way to reduce microplastic pollution. ECHA/PR/20/09.
} 
társadalmaknak a mikroműanyagok nagy helyettesítési költsége miatt, és például a műfüves pályák rugalmas borításánál, illetve arcápoló kozmetikumok esetében „teljesítményveszteség" is előfordulhat az alternatíva gyengébb paraméterei miatt.

Bár a Megállapodásban a felek kijelentik elkötelezettségüket a környezetvédelemben, valószínútlennek tartom a vitarendezési eljárás alkalmazását az EU részéről az EK-gal szemben, ha az nem kívánja a saját műszaki szabályozásának részévé tenni ezt az „olcsónak” nem minősíthető REACH-jogszabályt.

A REACH és/vagy az említett korlátozás átvételének hiányában az EK visszanyeri e területen az önálló jogalkotási lehetőségét. Ha az EK nem készíti el saját „REACH” jogszabályát vagy amennyiben például nem korlátozza a mikroműanyagot, a brit társadalom nem fog részt venni ebben a környezetvédelmi erőfeszítésben, de feltehetően olcsóbb vegyipari termékeket vásárolhat, illetve vállalkozásai rövid távú előnyre tehetnek szert a világpiacon, ahol nem alkalmazzák e jogszabályt.

\section{Következtetések}

A kitűzött célnak megfelelően a fentiekben az EU-EK szabadkereskedelmi megállapodás műszaki szabályozási részét jellemzem, és három mellékletét példának felhasználva bemutatom, hogy egy ex-tagállam milyen „TBT konform” módon tudja jogszabályi rendszerét nemzeti, illetve nemzetközi alapra helyezni. A példákra alapozott vizsgálatom és tényadatok sajátos csoportosításán alapuló megfontolás nem ad 100\%-os biztonsággal képet a brit műszaki szabályozási rendszer későbbi, tényleges múködéséről, de néhány kimenet már most látható. Ilyen a hatósági jogkörök „visszavétele” az EU-tól, dereguláció a versenyképesség javításáért stb. Meg nem válaszolt kérdés, hogy valóban gazdaságpolitikai megfontolás, vagy inkább a szuverenitás visszanyerésének abszolút igénye vezette-e a brit politikát, amikor az EGT keretében elképzelt, Brexit utáni együttműködés helyett egy eltérő műszaki szabályozású és a transzatlanti államokra kidolgozott, CETA-típusú szabadkereskedelmi megállapodás mellett tört lándzsát. Kérdéses továbbá, hogy az EU a Határozat 5. cikke szerinti vizsgálatát követően továbbra is egyenértékűnek ismeri-e el az EK-ban gyártott termékeket.

\section{Felhasznált irodalom}

A London School of Economic and Politikal Science, Centre for Economic Performance 01-07 alszámokon publikált Brexit-tanulmányai, amelyek közül a konkrétan hivatkozottak:

Dhingra, Swati - Thomas Sampson: Life after Brexit. London, Centre for Economic Performance, (é. n.). Online: https://cep.lse.ac.uk/pubs/download/brexit01.pdf

Dhingra, Swati - Gianmarco Ottaviano - Thomas Sampson - John Van Reenen: The consequences of Brexit for UK trade and living standards. London, Centre for Economic Performance, (é. n.). Online: https://cep.lse.ac.uk/pubs/download/brexit02.pdf 
CEFIC: 2021 Facts And Figures Of The European Chemical Industry (é. n.). Online: https:// cefic.org/a-pillar-of-the-european-economy/facts-and-figures-of-the-europeanchemical-industry/

Communication from the Commission on the precautionary principle COM(2000) 1 final (2000. február 2.). Online: https://eur-lex.europa.eu/LexUriServ/LexUriServ.do?uri=COM:2000:0001:FIN:EN:PDF

European Chemicals Agency: Scientific committees: EU-wide restriction best way to reduce microplastic pollution. ECHA/PR/20/09. Online: https://echa.europa.eu/ hu/-/scientific-committees-eu-wide-restriction-best-way-to-reduce-microplastic -pollution

European Commission: Good Regulatory Practices (GRPS) in TTIP - An introduction to the EU's revised proposal (2016. március 21.). Online: https://trade.ec.europa.eu/doclib/ docs/2016/march/tradoc_154381.pdf

\section{Jogi források}

A Tanács (EU) 2021/689 határozata (2021. április 29.) egyrészről az Európai Unió és az Európai Atomenergia-közösség, és másrészről Nagy-Britannia és ÉszakÍrország Egyesült Királysága közötti kereskedelmi és együttmúködési megállapodásnak, valamint az Európai Unió és Nagy-Britannia és Észak-Írország Egyesült Királysága közötti, a minősített adatok cseréjére és védelmére vonatkozó biztonsági eljárásokról szóló megállapodásnak az Unió nevében történő megkötéséről

Az Európai Közösségek Bizottságának közleménye (2.2.2000.) az elővigyázatossági elvről COM (2000) 1 final

Az Európai Parlament és a Tanács 1907/2006/EK rendelete (2006. december 18.) a vegyi anyagok regisztrálásáról, értékeléséről, engedélyezéséről és korlátozásáról (REACH), az Európai Vegyianyag-ügynökség létrehozásáról, az 1999/45/EK irányelv módosításáról, valamint a 793/93/EGK tanácsi rendelet, az 1488/94/EK bizottsági rendelet, a 76/769/EGK tanácsi irányelv, a 91/155/EGK, a 93/67/EGK, a 93/105/EK és a 2000/21/EK bizottsági irányelv hatályon kívül helyezéséről

Az Európai Parlament és a Tanács 1907/2006/EK rendelete (2006. december 18.) a vegyi anyagok regisztrálásáról, értékeléséről, engedélyezéséről és korlátozásáról (REACH), az Európai Vegyianyag-ügynökség létrehozásáról, az 1999/45/EK irányelv módosításáról, valamint a 793/93/EGK tanácsi rendelet, az 1488/94/EK bizottsági rendelet, a 76/769/EGK tanácsi irányelv, a 91/155/EGK, a 93/67/EGK, a 93/105/EK és a 2000/21/EK bizottsági irányelv hatályon kívül helyezéséről (EGT vonatkozású szöveg)

Az Európai Parlament és a Tanács 1272/2008/EK rendelete (2008. december 16.) az anyagok és keverékek osztályozásáról, címkézéséről és csomagolásáról, a 67/548/EGK és az 1999/45/EK irányelv módosításáról és hatályon kívül helyezéséről, valamint az 1907/2006/EK rendelet módosításáról (EGT-vonatkozású szöveg) 